\title{
A Common-Garden Study of Resource-Island Effects on a Native and an Exotic, Annual Grass After Fire
}

\author{
Amber N. Hoover ${ }^{1}$ and Matthew J. Germino ${ }^{2,3}$ \\ Authors are ${ }^{1}$ Research Technician and ${ }^{2}$ Professor, Department of Biological Sciences, Idaho State University, Pocatello, ID 83209, USA; and ${ }^{3}$ Research \\ Ecologist, USGS Forest and Rangeland Ecosystem Science Center, Snake River Field Station, Boise, ID 83706, USA.
}

\begin{abstract}
Plant-soil variation related to perennial-plant resource islands (coppices) interspersed with relatively bare interspaces is a major source of heterogeneity in desert rangelands. Our objective was to determine how native and exotic grasses vary on coppice mounds and interspaces (microsites) in unburned and burned sites and underlying factors that contribute to the variation in sagebrush-steppe rangelands of the Idaho National Lab, where interspaces typically have abiotic crusts. We asked how the exotic cheatgrass (Bromus tectorum L.) and native bluebunch wheatgrass (Pseudoroegneria spicata [Pursh] A. Löve) were distributed among the microsites and measured their abundances in three replicate wildfires and nearby unburned areas. We conducted a common-garden study in which soil cores from each burned microsite type were planted with seed of either species to determine microsite effects on establishment and growth of native and exotic grasses. We assessed soil physical properties in the common-garden study to determine the intrinsic properties of each microsite surface and the retention of microsite soil differences following transfer of soils to the garden, to plant growth, and to wetting/drying cycles. In the field study, only bluebunch wheatgrass density was greater on coppice mounds than interspaces, in both unburned and burned areas. In the common-garden experiment, there were microsite differences in soil physical properties, particularly in crust hardness and its relationship to moisture, but soil properties were unaffected by plant growth. Also in the experiment, both species had equal densities yet greater dry mass production on coppice-mound soils compared to interspace soils, suggesting microsite differences in growth but not establishment (likely related to crust weakening resulting from watering). Coppiceinterspace patterning and specifically native-herb recovery on coppices is likely important for postfire resistance of this rangeland to cheatgrass.
\end{abstract}

\section{Resumen}

La variación suelo-planta en relación con la isla de recursos de las plantas perennes y los montículos intercalados con la presencia de inter-espacios relativamente desnudos es la mayor fuente de heterogeneidad en pastizales áridos. Nuestro objetivo fue determinar cómo pastos nativos y exóticos varían con montículos y espacios intermedios (micro-sitios) en aéreas quemadas y no quemadas, y los factores principales que contribuyen a tal variación en los pastizales de Artemisia de Idaho National Lab. donde los inter-espacios típicamente tienen capas abióticas. Nos preguntamos cómo el pasto exótico cheatgrass (Bromus tectorum L.) y el pasto nativo bluebunch wheatgrass (Pseudoroegneria spicata [Pursh] A. Löve) se distribuyeron entre los micro-sitios, y medimos su abundancia en tres replicas de incendios forestales y áreas adyacentes no incendiadas. Se condujo un estudio común de jardín en el cual muestras de suelo de cada micro-sitio incendiado se sembró con semillas de cada especie para determinar el efecto de los micro-sitios en el establecimiento y crecimiento de los pastos nativos y exóticos. Las propiedades físicas del suelo se midieron como en un estudio típico de jardín para determinar las propiedades intrínsecas de la superficie de cada micro-sitio, y las diferencias en la retención de suelo en cada micro-sitio después de la transferencia de los suelos al jardín, para el desarrollo de las plantas, y para los ciclos de humectación/secado. En el primer estudio, sólo la densidad de bluebunch wheatgrass fue mayor en los montículos que en los inter-espacios en ambas áreas incendiadas y no incendiadas. En el experimento común de jardín, se presentaron diferencias en los micro-sitios relativos a las propiedades físicas del suelo, particularmente en la dureza de la corteza y su relación con la humedad, pero las propiedades del suelo no se afectaron por el crecimiento de las plantas. De igual manera en el experimento, ambas especies tuvieron iguales densidades pero mayor producción de materia seca en los suelos de los montículos comparado con los suelos de los inter-espacios, sugiriendo diferencias entre los micro-sitios en crecimiento pero no en establecimiento (probamente relacionado con el debilitamiento de la corteza como resultado del riego). Los patrones de los montículos e inter-espacios y específicamente la recuperación de herbáceas nativas en los montículos es probablemente importante para la resistencia de este pastizal a la invasión cheatgrass después de la presencia de incendios forestales.

Key Words: bluebunch wheatgrass, cheatgrass, coppice, heterogeneity, interspace, sagebrush

\section{INTRODUCTION}

Research was funded by Grant W911NF-07-1-0481 from the US Army Research Laboratory and Research Office, Grant EPS 0814387 from Idaho NSF EPSCoR, and the BLM.

Correspondence: Matthew J. Germino, USGS Forest and Rangeland Ecosystem Science Center, Snake River Field Station, Boise, ID 83706, USA. Email: mgermino@usgs.gov

Manuscript received 7 February 2011; manuscript accepted 6 November 2011.
Soil heterogeneity has been positively correlated with plant diversity and ecosystem functioning (Inouye and Tilman 1995; Rusch and Fernández-Palacios 1995; Reynolds et al. 1997; Tilman et al. 1997a, 1997b; Hector et al. 1999; Tylianakis et al. 2008). The most prevalent spatial heterogeneity among soil and 
plants within semiarid and arid rangelands is that related to resource islands, which often form when resources accumulate under shrub and other large perennial canopies (Charley and West 1975; Schlesinger et al. 1996). The resulting matrix gives rise to different microsites: coppice mounds (hereafter, "coppices"), where shrubs and resources are located, and interspaces, which are areas that have less vegetation and nutrients (e.g., Charley and West 1975; Schlesinger et al. 1996). Coppiceinterspace heterogeneity is a site attribute that could relate to resistance of rangeland ecosystems to disturbances (Chambers et al. 2007; Ravi et al. 2010).

Fire, postfire soil erosion, and other disturbances are increasing in some western rangelands of the United States (Stringham et al. 2003; Westerling et al. 2006; Sankey et al. 2009a). Differences in herbaceous vegetation and soil properties between coppices and interspaces remained following wildfire and wind erosion or seedings that involved soil disturbance, factors that might otherwise be expected to reduce the heterogeneity (Boyd and Davies 2010; Hoover 2010). Coppice-interspace heterogeneity was less evident where rangelands were in poor ecological condition and had more exotic annuals (Hilty et al. 2003). How plant-soil microsite variation (or heterogeneity) relates to disturbance and recolonization by native and exotic plants is an important question for rangelands (Wood et al. 1982; Boyd and Davies 2010).

Invasion of exotic annual grasses is problematic throughout the intermountain region of the western United States, particularly following wildfire, when the exotic annual Bromus tectorum L. (cheatgrass) increases in abundance (Stewart and Hull 1949; Brooks and Pyke 2001). Furthermore, cheatgrass increases fire frequency (Whisenant 1990), outcompetes native plants (Harris 1967; Melgoza et al. 1990; Reichenberger and Pyke 1990), and alters nutrient cycling (Norton et al. 2004; Rimer and Evans 2006; Sperry et al. 2006). Patterns of exotic grasses among coppice and interspace microsites have varied among previous studies, with reports of annual grass abundance being greater on coppices (Davies et al. 2007; Griffith 2010), greater on interspaces (Chambers et al. 2007), or equal on coppices and interspaces (Davies et al. 2007). Microsite differences in abundance of native and exotic plants could result from variation in their seed abundance, germination, growth, and/or survival.

Our first objective was to determine how abundance of the native perennial bunchgrass Pseudoroegneria spicata (Pursh) A. Löve (bluebunch wheatgrass) and cheatgrass differed on coppices and interspaces. We accomplished this using a field study of unburned sites and sites that were burned (and thus had no sagebrush on coppices) and impacted by postfire wind erosion (i.e., erosion reported in Sankey et al. 2009b, 2010). We hypothesized that bluebunch wheatgrass would be more abundant on shrubless coppice mounds than interspaces and that less microsite differences would be evident for cheatgrass, based on a previous report that native plant communities tended to be more heterogeneous among microsites than exotic plant communities (Hoover 2010). Our second objective was to experimentally verify that soil properties and not other attributes of the microsites (e.g., microtopography, intermicrosite interactions among plants) lead to differences in plant growth between burned coppices and interspaces. We focused on burned microsites for the second objective because cheatgrass increases following burning (Stewart and Hull 1949; Brooks and Pyke 2001). We created a common-garden study in which bluebunch wheatgrass or cheatgrass were seeded at a high rate onto the soils from burned coppices and interspaces. We hypothesized that 1) plant density would be greater on coppice soils than interspace soils, 2) dry mass production would be greater on coppices than interspaces, and 3) differences in surface hardness (crust present with high mechanical strength) would continue to be exhibited by the soils after removing them from their native microsite, indicating that crust formation results from physicochemical properties of the soil itself as opposed to microtopographic position (e.g., water flow between coppices and interspaces). Furthermore, crust hardness is likely dependent on soil moisture (as well as other soil properties that affect whether crusts can form), and soil moisture is affected by soil attributes and plant water use (which differs between bluebunch wheatgrass and cheatgrass). Therefore, we determined if and how crust strength relates to volumetric water content.

\section{METHODS}

\section{Study Area}

This study was conducted in the sagebrush steppe on the eastern Snake River Plain of southeastern Idaho at $\sim 1650-\mathrm{m}$ elevation in 2009. Sites were located at the southeastern corner of the Idaho National Laboratory at three postwildfire areas used as replicates: the Twin Buttes fire, which burned $\sim 3819$ ha in July 2007 (lat 43 $30^{\prime} 40.487^{\prime \prime} \mathrm{N}$, long $\left.112^{\circ} 40^{\prime} 15.086^{\prime \prime} \mathrm{W}\right)$; the Moonshiner fire, which burned $\sim 1081$ ha in August 2007 (lat $43^{\circ} 28^{\prime} 48.835^{\prime \prime} \mathrm{N}$, long $\left.112^{\circ} 38^{\prime} 3.724^{\prime \prime} \mathrm{W}\right)$; and the Highway 20 fire, which burned $\sim 486$ ha in July 2008 (lat $43^{\circ} 31^{\prime} 44.071^{\prime \prime} \mathrm{N}$, long $\left.112^{\circ} 46^{\prime} 2.025^{\prime \prime} \mathrm{W}\right)$. Burned sites were impacted by wind erosion in the months following fire as documented for the Twin Buttes and Moonshiner fires by Sankey et al. (2009b) and the Highway 20 fire through personal observation (A. Hoover, personal observation). Unburned control sites within $1-5 \mathrm{~km}$ of fire boundaries were used for comparison. The Idaho National Laboratory has a mean annual temperature of $5.6^{\circ} \mathrm{C}$ and receives $220 \mathrm{~mm}$ of precipitation annually (Anderson and Inouye 2001). Soils were comprised of silt loams (US Department of Agriculture-Natural Resources Conservation Service [USDA-NRCS] 2010). Biotic crusts were scarce, but abiotic, vesicular crusts were present on interspace surfaces. The region in which our study sites were located is relatively flat, and all the unburned and burned sites occur within the same NRCS Ecological Site and had similar topography, soil types, soil texture, and plant community assemblages. Initially, we considered that the experimental design could account for proximity of burned and unburned sampling sites by pairing them into three blocks; however, statistical tests (test for block effects in the analyses of variance [ANOVAs] described below) indicated that no such spatial variation existed.

The vegetation community was dominated by Artemisia tridentata Nutt. (big sagebrush; subspecies wyomingensis Beetle \& Young and tridentata; Anderson and Inouye 2001). Cheatgrass was frequently encountered but did not tend to dominate the vegetation community, especially compared to 
lower-elevation areas in the region where cheatgrass makes up a large portion of the vegetation community (Anderson and Inouye 2001). Other common shrub species included Artemisia tripartita Rydb. (threetip sagebrush) and Chrysothamnus viscidiflorus (Hook.) Nutt. (yellow rabbitbrush). Shrub canopy cover was $40 \% \pm 4 \mathrm{SE}$ at one of our unburned sites in July 2008 , and this appeared representative of the other unburned sites, whereas there were very few shrubs remaining in burned areas (only small rabbitbrush). Juniperus osteosperma (Torr.) Little (Utah juniper) was present in one unburned control area and present as burned and dead stumps or skeletons in the Moonshiner burned area. Common bunchgrasses included Poa secunda J. Presl (Sandberg bluegrass), Pseudoroegneria spicata (Pursh) A. Löve (bluebunch wheatgrass), and Elymus elymoides (Raf.) Swezey (squirreltail). Forbs such as Phlox hoodii Richardson (cushion phlox), Allium acuminatum Hook. (tapertip onion), and Crepis acuminata Nutt. (tapertip hawksbeard) were common. Sites were deemed to be in relatively good ecological condition and within the State 1 phase for reference plant communities for the appropriate NRCS Ecological Site Description, albeit with high bare soil exposure and considerable wind erosion of soil (Hoover 2010).

All sites were subject to light browsing by native herbivores, including pronghorn (Antilocapra americana), North American elk (Cervus elaphus), mule deer (Odocoileus hemionus), blacktailed jackrabbit (Lepus californicus), mountain cottontail (Sylvilagus nuttallii), and pygmy rabbit (Brachylagus idaboensis). In addition, the areas of the Moonshiner and Twin Buttes fires and two unburned areas were part of domestic grazing allotments though were mostly not impacted by livestock during the time of the study, and grazing was not permitted on burned sites during the study as a result of Bureau of Land Management postfire grazing policy. The Moonshiner burn area, Twin Buttes burn area, and one unburned area were part of a sheep grazing allotment $\left(0.08\right.$ animal unit month $\left.[\mathrm{AUM}] \cdot \mathrm{ha}^{-1}\right)$. A second unburned area was part of a cattle allotment $\left(0.2 \mathrm{AUM} \cdot \mathrm{ha}^{-1}\right)$. A low level of impact from livestock was evident in unburned areas, based on hoofprints, feces, and sightings of livestock in the vicinity. We did not sample microsites that had signs of plant or leaf removal. In addition, there are no natural sources of water for many tens of kilometers and no permanent water tank locations in our study areas.

\section{Field Study}

Vegetation Measurements. The number of live individuals of cheatgrass and bluebunch wheatgrass were recorded in $0.25-\mathrm{m}^{2}$ quadrats placed on the nearest coppice and nearest interspace at 20 randomly selected points (per microsite), within 32 ha of each unburned and burned site on three sampling dates (May, June, and July 2009). Each bunch of basal stems of a bunchgrass was recorded as one individual.

Statistical Analysis. We used PROC MIXED to conduct completely randomized split-plot, repeated-measures ANOVA with burn (unburned, burned) as the whole-plot fixed effect and microsite type (coppice, interspace) as the within-plot fixed effect for plant density $(n=3$ with $13-20$ subsamples per replicate; SAS version 9.2 [SAS Institute Inc. 2002-2008]). Data for both species were $\log _{10}$ transformed to meet the assumptions related to normality or homogeneity of variance. Original data is displayed in all figures (i.e., not back transformed). Factors were considered significant if $P \leq 0.05$.

\section{Common-Garden Study}

Core Collection. Soils cores were collected at the Twin Buttes wildfire study area, which was described previously. Intact and relatively undisturbed soil cores, $7.5 \mathrm{~cm}$ in diameter and $15.2 \mathrm{~cm}$ in height, were extracted using a clear-plastic Lexan cylinder inserted into the soil with a slide hammer (AMS, American Falls, ID). Twenty coppice and 20 interspace cores were collected at $10-\mathrm{m}$ increments along each of two $200-\mathrm{m}$ transects in May 2009, and 60 of the total 80 cores were randomly selected for use in the experiment. Transects were located $>13 \mathrm{~km}$ apart.

Experimental Design and Measurements. We used a two-factor design with microsite type (coppice or interspace) and vegetation type (seeded with bluebunch wheatgrass or cheatgrass or unseeded control). Cores were left in the lexan cylinders and randomly placed in a grid with 14 columns and six rows within a $244 \times 95 \times 28 \mathrm{~cm}$ outdoor sandbox at the Idaho State University Plant Sciences Research Facility in Pocatello, Idaho. The sandbox was filled flush with the soil surface in the lexan cylinders with coarse-grained sand. Ten coppice and 10 interspace cores were seeded with bluebunch wheatgrass, were seeded with cheatgrass, or were unseeded controls. Bluebunch wheatgrass seed (Anatone) was obtained from The Maple Leaf Company (Ephraim, UT), and cheatgrass seed was collected in Johnson Canyon, Box Elder County, Utah. Germination rates in the laboratory for bluebunch wheatgrass and cheatgrass seed were $52 \%$ and $86 \%$, respectively.

To adjust for differences in germination rate between bluebunch wheatgrass and cheatgrass, approximately 30 seeds of bluebunch wheatgrass $(\sim 0.48 \mathrm{~g})$ and 18 seeds of cheatgrass $(\sim 0.45 \mathrm{~g})$ were broadcast over the appropriate cores to achieve 15 germinants per replicate in mid-May. Ten additional seeds of each species were placed into 1-mm-deep surface furrows, made by forceps, on the surface of the core and covered lightly with soil in mid-May. Ten 1-mm-deep surface furrows were made and covered but not seeded on control cores. We did not want our study to merely confirm that hard abiotic crusts inhibit seed penetration and germination. Instead, we wanted to determine if there were other intrinsic attributes of the soil microsites that affect germination and initial growth. Therefore, we initially dropped seeds onto the surface but then proceeded to embed seeds into shallow furrows into the soil (one to several $\mathrm{mm}$ deep) and the covered seeds with soil. Nontarget species were scarce and were periodically removed from cores planted with bluebunch wheatgrass or cheatgrass but were not removed from control cores. Target species were not removed from any of the cores.

Soil cores were watered with either distilled or reverseosmosis water throughout the experiment. To mimic snowmelt and spring rains, $23 \mathrm{~mm}$ of water were added to the cores on three different days $(69 \mathrm{~mm}$ total; one was the day before planting), and on nine different days, $\sim 10 \mathrm{~mm}$ of water were added (90 $\mathrm{mm}$ total) for a total of $159 \mathrm{~mm}$ during the first $3 \mathrm{wk}$ following the start of the experiment. No supplemental water was provided for the following 7 wk from early June through 
late July. Approximately $10 \mathrm{~mm}$ of water were added once per week during the final $3 \mathrm{wk}$ of the experiment to ensure that soil water was similar to field conditions, which were measured in a corresponding study (Hoover 2010). The total supplemental water added to background precipitation was $189 \mathrm{~mm}$. Background precipitation was $210 \mathrm{~mm}$ during the course of the study. ${ }^{1}$

The number of grasses in each core and the height $( \pm 1 \mathrm{~mm})$ of the longest blade of each individual grass were recorded in early June and mid-August. Replication was 10 for all treatment combinations except for density and height measurements on coppice soils seeded with cheatgrass in August (because of lost replicates, $n=9$ and 8 , respectively). In midAugust, biomass was harvested from all cores using scissors, separated into live and senesced portions, dried at $80^{\circ} \mathrm{C}$ for $\geq 24 \mathrm{~h}$, and weighed ( $\pm 0.001 \mathrm{~g}$ ). We measured mechanical strength and volumetric water content (VWC) on five replicate cores of each treatment combination at the end of the experiment in mid-August 2009. One replicate was lost for mechanical strength measurements for cheatgrass on coppice soils and another for bluebunch wheatgrass on interspace soils. Therefore, each of these treatments combinations had four rather than five replicates. Mechanical strength (unconfined compressive strength) was measured using a pocket penetrometer (Geotest Instrument Corporation, Evanston, IL), and VWC from 0 to $5 \mathrm{~cm}$ was measured using an ECH2O EC-5 soil moisture probe (Decagon Devices, Pullman, WA).

After dry mass collection, soil cores were randomized, and nine coppices and interspaces were wetted and used to determine the relationship between mechanical strength and gravimetric water content (GWC) as soils dried. We added $100 \mathrm{ml}$ of tap water to each core, and measurements were made on dry soil prior to water addition, $1 \mathrm{~h}$ postwetting, and $4 \mathrm{~d}$ and $1.5 \mathrm{~h}$ following water addition. Mechanical strength was measured with the pocket penetrometer, and surface soils (top 4-8 $\mathrm{mm}$ ) were collected, weighed $( \pm 0.001 \mathrm{~g})$, dried at $70^{\circ} \mathrm{C}$ for $24 \mathrm{~h}$, and weighed again to determine GWC.

Statistical Analysis. Repeated-measures ANOVA was conducted with PROC MIXED to determine how grass density or height responded to microsite type (coppice, interspace) and vegetation type (bluebunch wheatgrass, cheatgrass) as fixed factors repeated in time (June, August; SAS version 9.2). Height data were $\log _{10}$ transformed to meet the assumptions related to normality. Post hoc comparisons were conducted when interaction terms were significant $(P \leq 0.05)$. A Holm's adjustment was used to control for experiment-wise error rate. Dry mass data violated the assumptions related to normality and homogeneity of variance even when data transformations were used; therefore, a Brunner-Dette-Monk analysis was done using the asbio package in R version 2.10.1 (Aho 2010; R Development Core Team 2009). The Brunner-Dette-Monk test is a rank-based permutation procedure that does not have assumptions related to normality or homogeneity of variance. PROC MIXED was used to perform a two-way ANOVA to determine how soil mechanical strength and VWC responded to microsite type (coppice, interspace) and vegetation type (bluebunch wheatgrass, cheatgrass, control) as fixed effects (SAS version 9.2). An analysis of covariance was conducted using PROC MIXED with

${ }^{1}$ Available at: http://lwf.ncdc.noaa.gov/oa/ncdc.html. mechanical strength as the response variable, GWC as the covariate, and microsite type as the categorical variable, and each replicate was repeated in time (SAS version 9.2). Mechanical strength and GWC data were $\log _{10}$ transformed to meet the assumptions related to normality or homogeneity of variance. Factors were considered significant if $P \leq 0.05$.

\section{RESULTS}

\section{Field Study}

There were twice as many bluebunch wheatgrass individuals on coppices than interspaces over all unburned and burned sites and all months (Fig. 1; Table 1). Cheatgrass density was not different between coppices and interspaces of unburned or burned sites in any month (Fig. 2; Table 1).

\section{Common-Garden Study}

Dry mass production was $60 \%$ greater on coppice soils than interspace soils across all vegetation treatments, for both live (green) dry mass as well as live and accumulated senesced dry mass combined (Fig. 3; Table 2). There were no differences in plant density or height (Holm's $P>0.05$ ) on coppices compared to interspace soils for either grass species (Fig. 4; Table 2). Few plants emerged on unseeded controls, and mean plant density on controls was $0 \pm 0.1 \mathrm{SE}$ in June and $0 \pm 0.2 \mathrm{SE}$ in August for coppice soils and $1 \pm 0.3 \mathrm{SE}$ in June and $0 \pm 0.3$ SE in August for interspace soils $(n=10$; data not shown). Species present on unseeded control cores included cheatgrass and bluebunch wheatgrass on coppice soils and Agropyron cristatum (L.) Gaertn. (crested wheatgrass) on interspace soils.

Interspace soils had $60 \%$ greater mechanical strength and $5 \%$ more volumetric water content than coppice soils across all vegetation treatments (Fig. 5; Table 2). Differences in crusting between the microsite soils were most evident when soils were dry and were not as apparent (or were absent) in soils having more than $20 \%$ gravimetric water content (Fig. 6; Table 2).

\section{DISCUSSION}

Our experimental results suggest that coppices can support greater growth of the grasses we evaluated, which is in agreement with previous studies (Wood et al. 1978, 1982; Eckert et al. 1986b; Davies et al. 2007). This finding compares well with the microsite heterogeneity observed for bluebunch wheatgrass in our field study but not the homogeneous distribution of cheatgrass among microsites. A notable feature of our field sites was a diverse and abundant assemblage of native herbs that is often absent in Wyoming sagebrush rangeland.

\section{Differences in Physical Properties Among Microsites}

Several of the properties unique to each microsite have strong effects on plant growth. Interspaces form hard surface crusts and have lower infiltration than coppices (Eldridge and Rosentreter 2004). Mechanical strength of soil surfaces and VWC were greater on interspaces than coppices, in burned as well as unburned areas of our study sites at the Idaho National Laboratory (Hoover 2010). In the current study, these same 


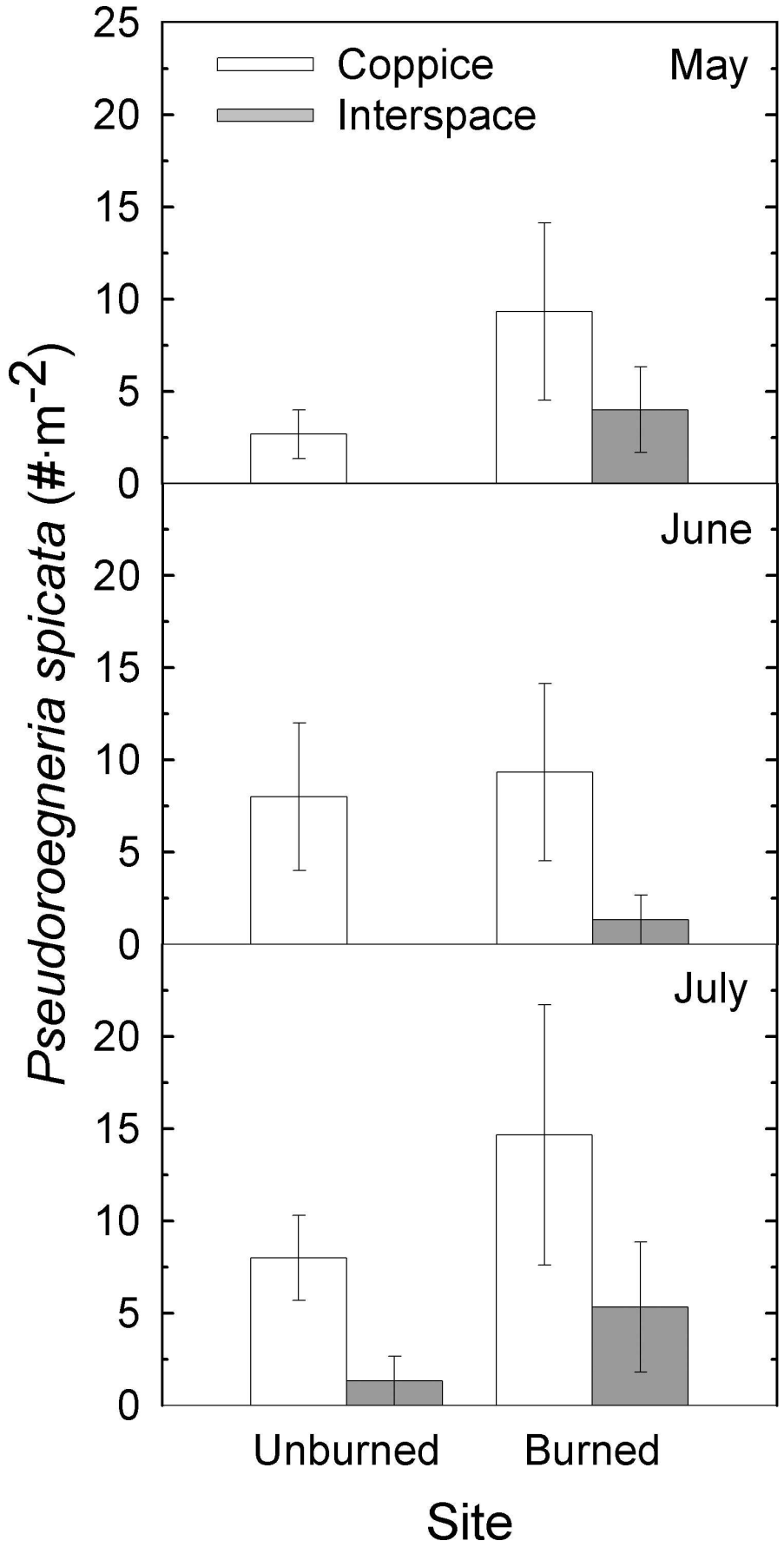

Figure 1. Density of bluebunch wheatgrass (mean $\pm 1 \mathrm{SE}$ ) per $0.25 \mathrm{~m}^{2}$ on coppice and interspace microsites in unburned and burned sites during May, June, and July 2009 ( $n=3$, using Twin Buttes, Moonshiner, and Highway 20 burn sites as replicates with unburned control sites).

attributes of greater surface hardness and soil water were present for burned interspace compared with burned coppice soils removed from field settings and relocated to a garden (Fig. 5). Although the persistence of crust re-formation in the common garden revealed that crusting is an intrinsic property of interspace soils, wetting reduced the hardness of interspaces and presence of crust relative to coppices (Figs. 5 and 6). Greater organic matter content in coppices than interspaces probably contributes to the tendency for hard physical crusts to form on interspaces (Lado et al. 2004; Singer and Shainberg 2004).
The greater VWC we report for interspaces compared with coppices differs from some previous reports. Although we did not assess soil water availability as water potential, microsite differences in VWC were mirrored by measurements of water potential in a laboratory experiment (burned coppice soils with $8 \%$ VWC had water potentials of $-3.02 \pm 0.384$ SE MPa, burned interspace soils with $10 \%$ VWC had water potentials of $-1.93 \pm 0.352 \mathrm{SE} \mathrm{MPa}$; Hoover and Germino, unpublished data). Interspaces have been reported to have lower VWC than coppices in unburned sites of other studies (e.g., Davies et al. 2007, 2009). Our common-garden study conditions were relatively wet, and water was not able to run off the cores even when crusting occurred. We observed similar patterns across three replicate sites burned by wildfire in our 2009 field study because there was little topography at the field sites and water pooled on interspaces (Eckert et al. 1986a; Dobrowolski et al. 1990; Hoover 2010). When water is given the opportunity to pool on top of and slowly infiltrate on interspaces, the water is retained because of less plant water use.

\section{Reconciling Field and Experimental Differences}

Several key interacting factors are candidate explanations for 1) why dry mass of both species was greater on coppices in the common garden yet 2) density (plants $\cdot \mathrm{m}^{-2}$ ) of bluebunch wheatgrass but not cheatgrass was greater on coppices in the field. Competing herbs were present on coppices and to a lesser extent interspaces in the field (Hoover 2010) and may have contributed to the pattern of grass abundances on the microsites in the field and garden, along with microsite variation in water, nutrients, and seed availability and emergence. Native herbaceous vegetation reduces exotic annual grass establishment, and their abundances are often negatively correlated (Tilman 1997; Anderson and Inouye 2001; Booth et al. 2003; Chambers et al. 2007).

The common-garden experiment received more water and wetting events than is usual for Wyoming big sagebrush-steppe ecosystems, though the resulting range of soil VWC was similar to values we observed over several years at the field sites (Sankey et al. 2009b; Hoover 2010). Wetter and therefore weaker crusts would pose less impediment to seed contact, retention, and establishment on interspace soils in the common garden, explaining the equal densities of both grasses on coppices and interspaces (Figs. 4-6). Although water abundance was useful for explaining microsite effects on plant establishment and densities, it could not explain relatively reduced dry mass production on interspaces (they were also relatively wetter). Thus, microsite differences in dry mass production may have resulted from microsite variation in nutrients.

Coppices had increased nutrients compared to interspaces in unburned and burned areas (Stubbs and Pyke 2005; Davies et al. 2007, 2009). Nitrogen is often a limiting resource in semiarid environments, particularly when phosphorus is more available because of low carbonate content of soil, such as at our field sites (James and Jurinak 1978; Lajtha and Schlesinger 1988; Hoover 2010). Total nitrogen and electrical conductivity were greater on burned coppices compared with burned interspaces at our field sites (Hoover 2010). Available nitrogen $\left(\mathrm{NH}_{4}^{+}\right.$and $\left.\mathrm{NO}_{3}^{-}\right)$was greater on burned coppices of $A$. tridentata and Juniperus occidentalis Hook. compared with 
Table 1. Degrees of freedom, $F$ values, and $P$ values for split-plot, repeated-measures analysis of variance for density of $P$ seudoroegneria spicata and Bromus tectorum in the field study.

\begin{tabular}{lccc}
\hline \multicolumn{1}{c}{ Effect } & df & $F$ & $P$ \\
\hline P. spicata density & & & 0.004 \\
Microsite type & 1,4 & 35.88 & 0.404 \\
Burn & 1,4 & 0.87 & 0.571 \\
Microsite type $\times$ burn & 1,4 & 0.38 & 0.039 \\
Month & 2,16 & 4.01 & 0.211 \\
Month $\times$ microsite type & 2,16 & 1.72 & 0.226 \\
Month $\times$ burn & 2,16 & 1.63 & 0.944 \\
Month $\times$ microsite type $\times$ burn & 2,16 & 0.06 & 0.625 \\
B. tectorum density & & & 0.73 \\
Microsite type & 1,4 & 0.28 & 0.132 \\
Burn & 1,4 & 0.14 & 0.018 \\
Microsite type $\times$ burn & 1,4 & 3.58 & 0.915 \\
Month & 2,16 & 5.26 & 0.545 \\
Month $\times$ microsite type & 2,16 & 0.09 & 0.943 \\
Month $\times$ burn & 2,16 & 0.63 & \\
Month $\times$ microsite type $\times$ burn & 2,16 & 0.06 & \\
\hline
\end{tabular}

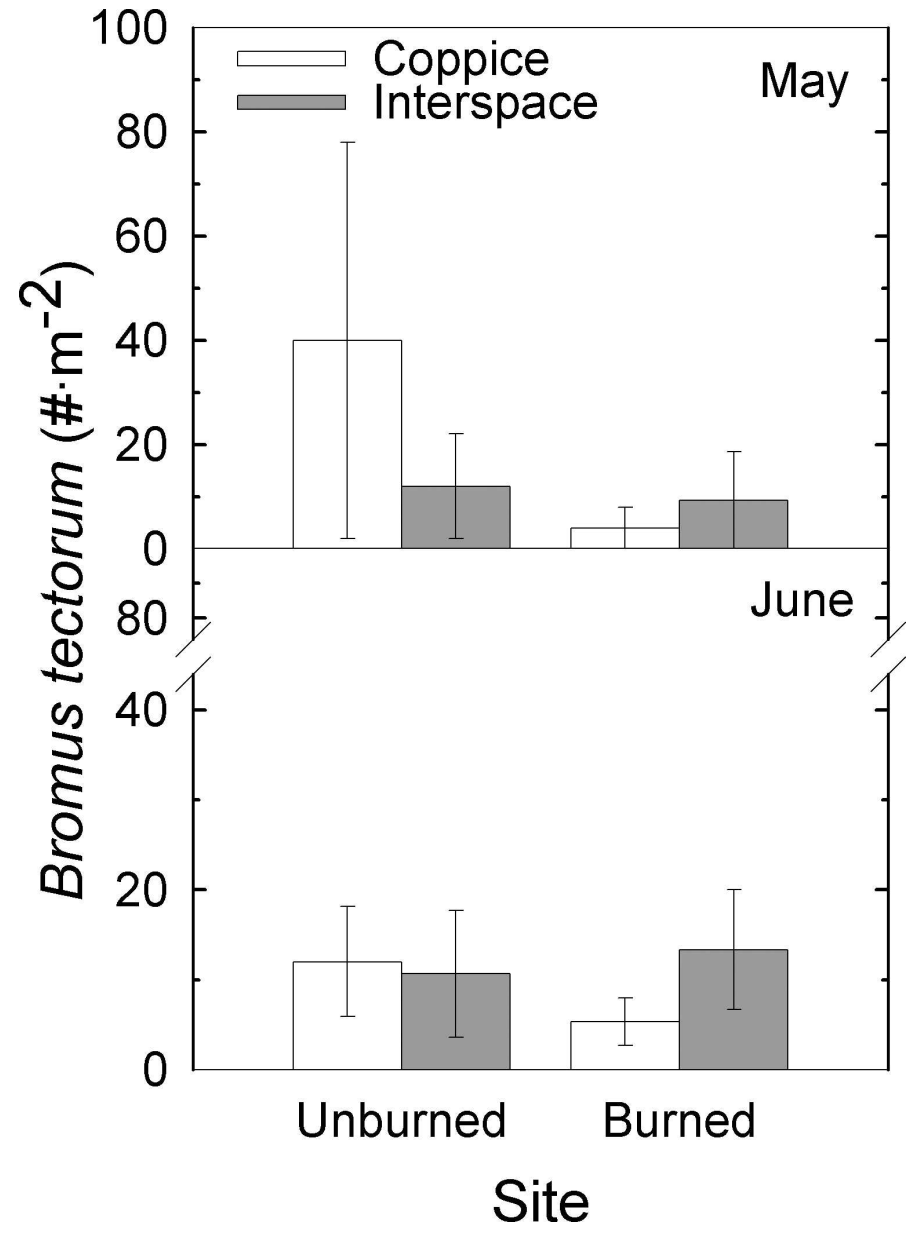

Figure 2. Density of cheatgrass (mean $\pm 1 \mathrm{SE}$ ) per $0.25 \mathrm{~m}^{2}$ on coppice and interspace microsites in unburned and burned sites during May and June 2009 ( $n=3$, using Twin Buttes, Moonshiner, and Highway 20 burn sites as replicates with unburned control sites). Data for July 2009 were not displayed because means were zero.

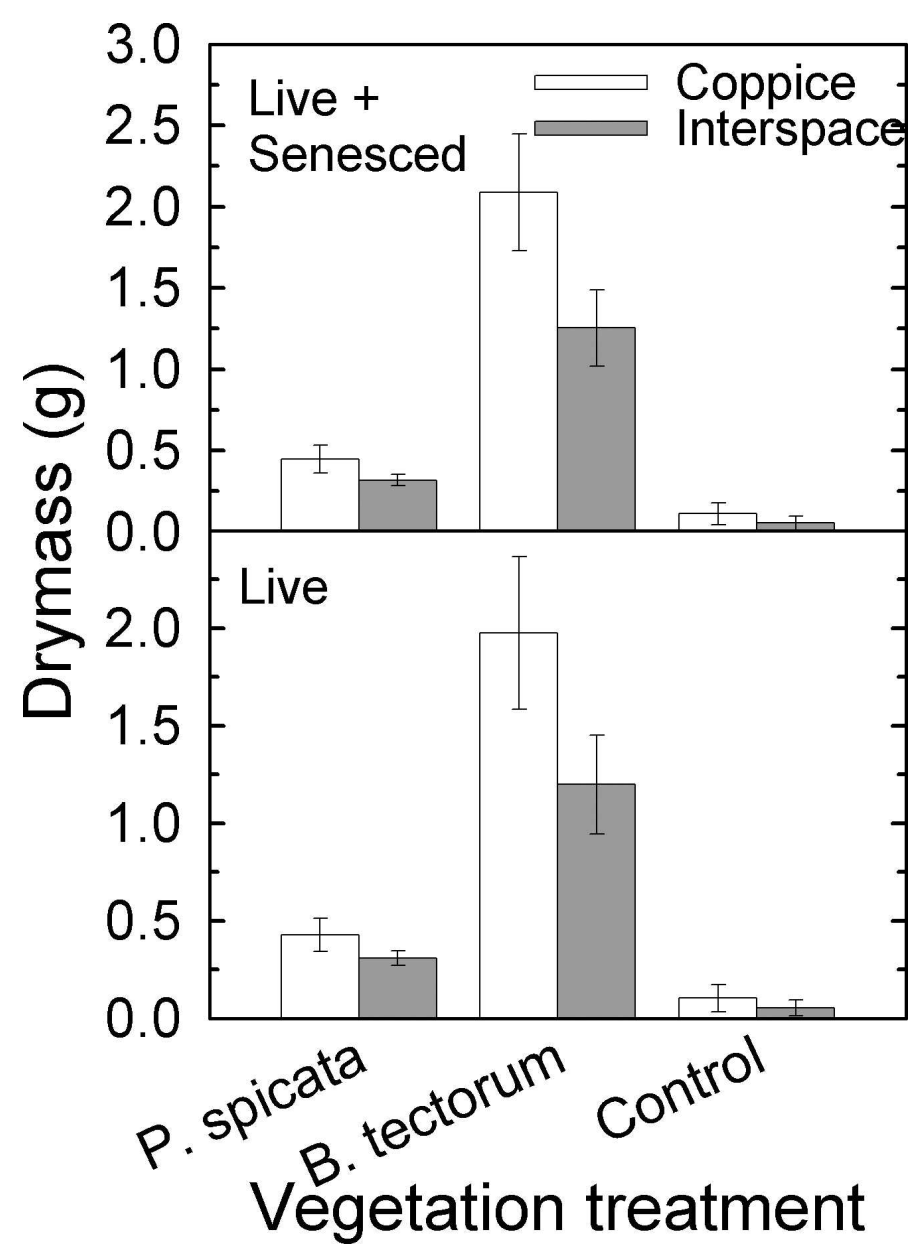

Figure 3. Live + senesced and live dry mass for coppice and interspace microsites seeded with bluebunch wheatgrass, seeded with cheatgrass, or unseeded controls $(n=10$; mean $\pm 1 \mathrm{SE})$. 
Table 2. Degrees of freedom, $F$ values, and $P$ values from the common-garden study for repeated-measures analysis of variance (ANOVA) for plant density and plant height, Brunner-Dette-Monk tests for plant dry mass (live + senesced and live), two-way ANOVA for mechanical strength and volumetric water content, and analysis of covariance (ANCOVA) for soil mechanical strength.

\begin{tabular}{|c|c|c|c|}
\hline Effect & df & $F$ & $P$ \\
\hline \multicolumn{4}{|l|}{ Repeated-measures ANOVA } \\
\hline \multicolumn{4}{|l|}{ Plant density } \\
\hline Microsite type & 1,35 & 0.7 & 0.409 \\
\hline Vegetation type & 1,35 & 10.46 & 0.003 \\
\hline Microsite type $\times$ vegetation type & 1,35 & 0.83 & 0.369 \\
\hline Month & 1,35 & 16.28 & $<0.000$ \\
\hline Month $\times$ microsite type & 1,35 & 0.03 & 0.854 \\
\hline Month $\times$ vegetation type & 1,35 & 33.58 & $<0.000$ \\
\hline Month $\times$ microsite type $\times$ vegetation type & 1,35 & 2.26 & 0.142 \\
\hline \multicolumn{4}{|l|}{ Plant height } \\
\hline Microsite type & 1,34 & 0.46 & 0.504 \\
\hline Vegetation type & 1,34 & 3.26 & 0.08 \\
\hline Microsite type $\times$ vegetation type & 1,34 & 7.89 & 0.008 \\
\hline Month & 1,34 & 103.87 & $<0.000$ \\
\hline Month $\times$ microsite type & 1,34 & 4.01 & 0.053 \\
\hline Month $\times$ vegetation type & 1,34 & 11.02 & 0.002 \\
\hline Month $\times$ microsite type $\times$ vegetation type & 1,34 & 0.01 & 0.93 \\
\hline \multicolumn{4}{|l|}{ Brunner-Dette-Monk test } \\
\hline \multicolumn{4}{|l|}{ Plant dry mass (Live + senesced) } \\
\hline Microsite type & 1,44 & 5.4 & 0.025 \\
\hline Vegetation type & 2,44 & 85.1 & $<0.000$ \\
\hline Microsite type $\times$ vegetation type & 2,44 & 0.2 & 0.8 \\
\hline \multicolumn{4}{|l|}{ Plant dry mass (Live) } \\
\hline Microsite type & 1,42 & 3.9 & 0.055 \\
\hline Vegetation type & 2,42 & 64.3 & $<0.000$ \\
\hline Microsite type $\times$ vegetation type & 2,42 & 0.3 & 0.73 \\
\hline \multicolumn{4}{|l|}{ Two-way ANOVA } \\
\hline \multicolumn{4}{|l|}{ Soil mechanical strength } \\
\hline Microsite type & 1,23 & 7.06 & 0.014 \\
\hline Vegetation type & 2,23 & 1.3 & 0.292 \\
\hline Microsite type $\times$ vegetation type & 2,23 & 0.81 & 0.455 \\
\hline \multicolumn{4}{|l|}{ Soil volumetric water content } \\
\hline Microsite type & 1,23 & 20.37 & $<0.000$ \\
\hline Vegetation type & 2,23 & 2.55 & 0.1 \\
\hline Microsite type $\times$ vegetation type & 2,23 & 1.84 & 0.181 \\
\hline \multicolumn{4}{|l|}{ ANCOVA } \\
\hline \multicolumn{4}{|l|}{ Soil mechanical strength } \\
\hline Gravimetric water content & 1,29 & 69.85 & $<0.000$ \\
\hline Microsite type & $1,13.6$ & 3.83 & 0.071 \\
\hline Gravimetric water content $\times$ microsite type & $1,28.4$ & 6.55 & 0.016 \\
\hline Time & $2,34.4$ & 8.34 & 0.001 \\
\hline Gravimetric water content $\times$ time & $2,40.8$ & 0.6 & 0.552 \\
\hline Microsite type $\times$ time & $2,36.5$ & 0.96 & 0.393 \\
\hline \multicolumn{4}{|l|}{ Gravimetric water content $\times$ microsite } \\
\hline type $\times$ time & $2,40.8$ & 0.51 & 0.602 \\
\hline
\end{tabular}

burned interspaces (Stubbs and Pyke 2005; Davies et al. 2009). Growth of bluebunch wheatgrass and cheatgrass increase with nitrogen addition (Monaco et al. 2003; James 2008a, 2008b). Greater plant-available nitrogen on coppices compared with interspaces could contribute to the greater dry mass production of bluebunch wheatgrass and cheatgrass on coppices versus interspaces in our common-garden study (Fig. 3). However, $\mathrm{pH}$ and $\mathrm{C}: \mathrm{N}$ did not differ between coppices and interspaces, and thus the proportion of $\mathrm{N}$ as $\mathrm{NH}_{4}$ or $\mathrm{NO}_{3}$ might be similar on coppices and interspaces (Hoover 2010). 


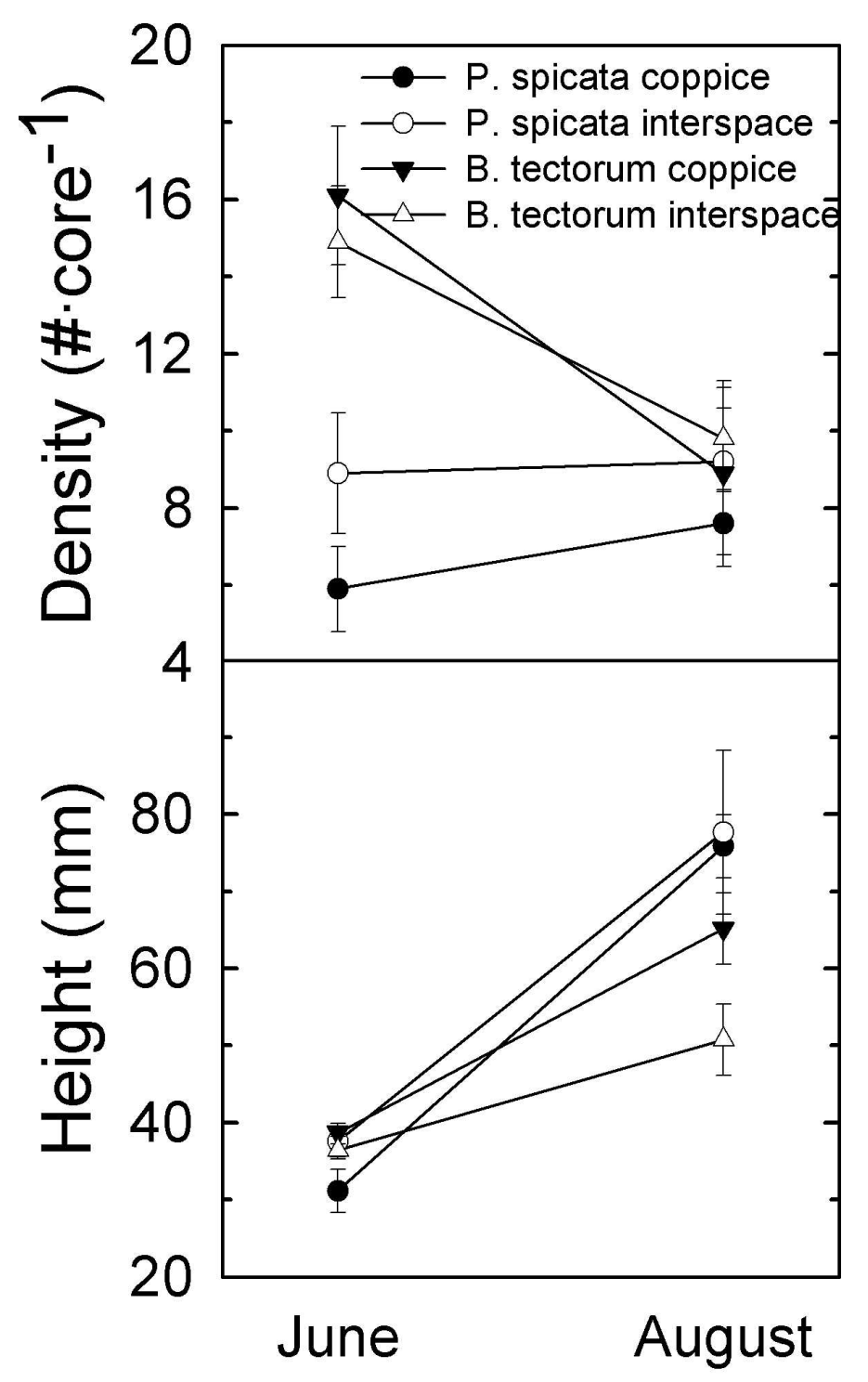

Month

Figure 4. Grass density and height in June and August for coppice and interspace microsites seeded with bluebunch wheatgrass or cheatgrass (means $\pm 1 \mathrm{SE}$ ); $n=10$ for all treatment combinations except August density for coppices seeded with cheatgrass $(n=9)$ and August height for coppices seeded with cheatgrass $(n=8)$.

Seed production is likely greater on coppices, and seeds may furthermore be moved from interspaces to coppices along with wind-eroded sediments (Fig. 1; Hassan and West 1986; Coppinger et al. 1991). Even though cheatgrass was no less abundant on interspaces compared to coppices in the field, its abundance on interspaces could nonetheless be limited to some degree by seed abundance and germination. The large and lightweight caryopses of cheatgrass are not conducive to good soil contact on interspace crusts, and the lack of litter cover on interspaces likely causes germination to be less than optimal (Evans and Young 1970, 1984). However, any seed limitation on interspaces was apparently offset by other factors, such as the long awns that likely contribute to seed retention on crusts, germination in late autumn when moisture-induced crust

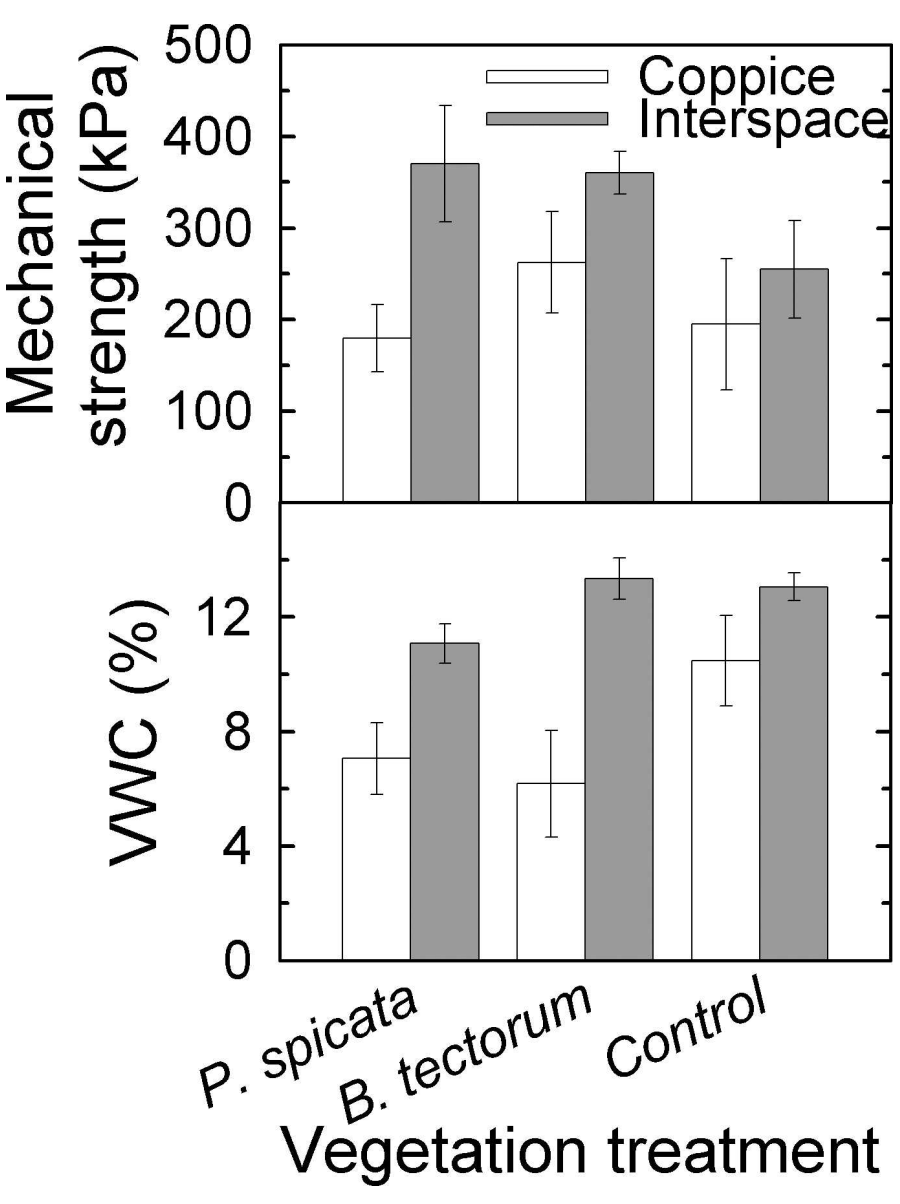

Figure 5. Mechanical strength and volumetric water content (VWC; 05-cm depth) for coppice and interspace microsites seeded with bluebunch wheatgrass or cheatgrass or unseeded controls (means \pm 1 $\mathrm{SE}) ; n=5$ for all treatment combinations except mechanical strength for coppices seeded with cheatgrass $(n=4)$ and VWC for interspaces seeded with bluebunch wheatgrass $(n=4)$.

softening is more likely, and high percent germination rates for whatever seed is retained in interspaces (Figs. 2 and 7; Hull and Hansen 1974; Young and Evans 1975). These potential differences in seed abundance and emergence were likely in the field but not in the common garden, where we normalized seed availability among the microsites and subsequently observed no differences in plant density among the microsite types.

\section{IMPLICATIONS}

Coppice-interspace variation is a fundamental aspect of sagebrush-steppe ecosystems (Charley and West 1975), and management practices, including mowing, chaining, seeding, prescribed burning, and organic matter amendments, could alter coppice-interspace heterogeneity. Wildfire, wind erosion, and invasion of nonnative plants all interact to influence the heterogeneity related to coppices and interspaces in rangelands of the Intermountain West. Variation related to coppices and interspaces, in turn, appears pivotal to site resistance to invasion (Chambers et al. 2007; Griffith 2010). Our field results indicate that interspaces are important for populations of cheatgrass, but our common-garden study demonstrated that 


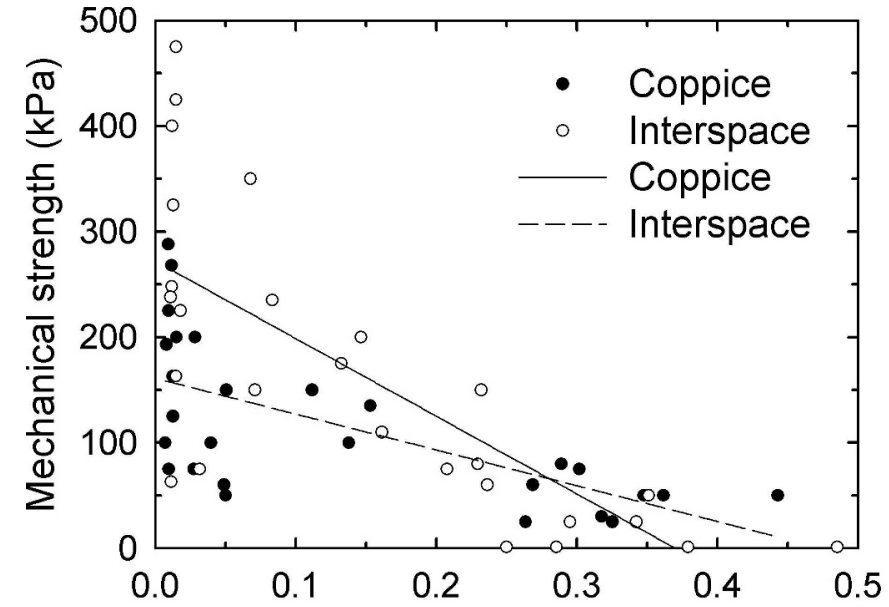

Gravimetric water content ( $g$ water.g dry soil ${ }^{-1}$ )

Figure 6. Mechanical strength versus gravimetric water content for coppice and interspace soil cores from the common-garden study $(n=9)$. Best-fit linear regression lines are shown.

coppices would promote greater cheatgrass in the absence of competitors. From these findings, we can make testable predictions on how changes in the distributions of coppices and interspaces across the landscape might influence cheatgrass invasion. If the landscape became dominated by coppice-like soils (i.e., because of an increase in coppice-forming plants), relative abundances of cheatgrass may decrease because grasses such as bluebunch wheatgrass grow well on coppice soils and would thus increase. However, a coppice-rich landscape that had lost its native herbs would be highly vulnerable to cheatgrass, such as where shrubs have been increased and herbs

\section{Effect on B. tectorum}

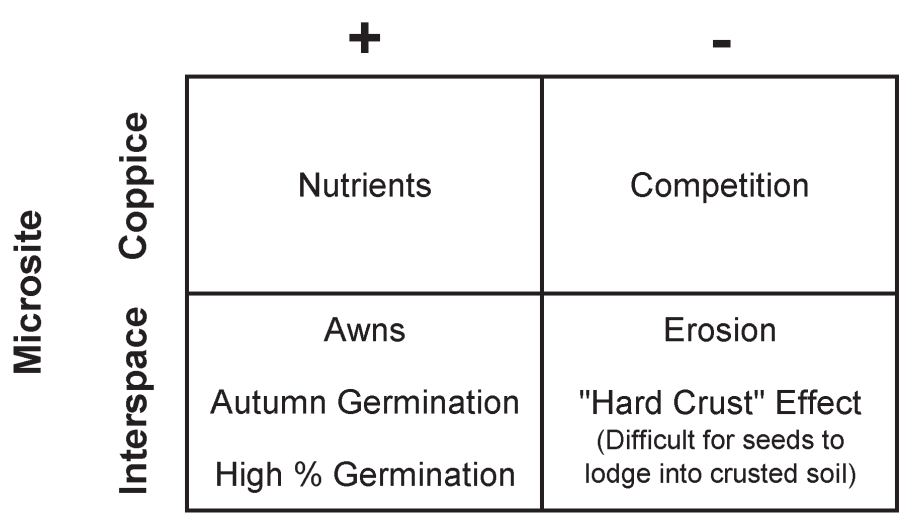

Figure 7. Hypothesized positive and negative effects of coppices and interspaces on cheatgrass, and the site or organismal factors underlying the effects. We propose that the positive and negative effects counterbalance each other such that cheatgrass exhibits similar abundances on the microsites types in the sites we evaluated. Fertility might favor growth on coppices, but competition may reduce growth. Erosion on the hard crusts and lack of standing litter could reduce seed abundance on interspaces, but the seed awns would help retention of seeds on interspaces, as would an ability to germinate under cool autumn conditions when crusts are not as hard. High germination rates result in less seed limitation to population abundance. depleted by some grazing practices. If the landscape became dominated by interspace-like soils, site-level abundances of cheatgrass might increase because native herbs like bluebunch wheatgrass are scarce on interspaces and their abundance would be expected to decrease dramatically at the landscape level. Thus, the net outcome of an increase in interspace-like soils or an increase in coppice-like soils combined with paucity of native vegetation would be a loss of resistance to cheatgrass and of resilience to disturbance (D'Antonio and Chambers 2006; Chambers et al. 2007). Soil-fertility patterning related to native vegetation impacts cheatgrass and is likely a meaningful consideration when making management decisions aimed at increasing or maintaining rangeland health. Native herb presence on coppices that are formed primarily by shrubs appears likely to be a key element of site resistance to cheatgrass after fire. These considerations suggest that coppice-forming species like big sagebrush may be needed to improve postfire resistance.

\section{ACKNOWLEDGMENTS}

Nancy Glenn, Lachlan Ingram, Sue Phillips, and Joel Sankey provided discussion and comments. S. M. Stoller Corporation and Roger Blew in particular provided logistical and technical support for the fieldwork conducted at the Idaho National Laboratory. We also thank Sarah Bachman, Lala Chambers, Jeremy Greth, Sara Kaiser, Janet Prevéy, and Zach Njorge for field and lab assistance. Ken Aho, Ernest Keeley, and Teri Peterson provided statistical advice. Cheatgrass seed was collected and provided to us by Thomas Monaco at the USDA-ARS, Forage and Range Research Laboratory, Utah State University, Logan, Utah. Any use of trade, product, or firm names is for descriptive purposes only and does not imply endorsement by the US government.

\section{LITERATURE CITED}

Ано, К. 2010. Asbio package. Available at: http://cran.r-project.org/web/packages/ asbio/index.html. Accessed 18 May 2010.

Anderson, J. E., And R. S. Inouye. 2001. Landscape-scale changes in plant species abundance and biodiversity of a sagebrush steppe over 45 years. Ecological Monographs 71:531-556.

Booth, M. S., M. M. Caldwell, and J. M. Stark. 2003. Overlapping resource use in three Great Basin species: implications for community invasibility and vegetation dynamics. Journal of Ecology 91:36-48.

Boyd, C. S., AND K. W. Davies. 2010. Shrub microsite influences post-fire perennial grass establishment. Rangeland Ecology \& Management 63:248-252.

Brooks, M. L., And D. A. PYKE. 2001. Invasive plants and fire in the deserts of North America. In: K. E. M. Galley and T. P. Wilson [Eds.]. Proceedings of the Invasive Species Workshop: The Role of Fire in the Control and Spread of Invasive Species. Fire Conference 2000: The First National Congress on Fire, Ecology, Prevention and Management. Tallahassee, FL, USA: Tall Timbers Research Station. Miscellaneous Publication No. 11. p. 1-14

Chambers, J. C., B. A. Roundy, R. R. Blank, S. E. Meyer, and A. Whittaker. 2007. What makes Great Basin sagebrush ecosystems invasible by Bromus tectorum? Ecological Monographs 77:117-145.

Charley, J. L., and N. E. West. 1975. Plant-induced soil chemical patterns in some shrub-dominated semi-desert ecosystems of Utah. Journal of Ecology 63:945-964.

Coppinger, K. D., W. A. Reiners, I. C. Burke, and R. K. Olson. 1991. Net erosion on a sagebrush steppe landscape as determined by cesium-137 distribution. Soil Science Society of America Journal 55:254-258.

D'Antonio, C. M., And J. C. Chambers. 2006. Using ecological theory to manage or restore ecosystems affected by invasive plant species. In: D. Falk, M. Palmer, 
and J. Zedler [EDS.]. Foundations of restoration ecology. Covelo, CA, USA: Island Press. p. 260-279.

Davies, K. W., J. D. Bates, and J. J. James. 2009. Microsite and herbaceous vegetation heterogeneity after burning Artemisia tridentata steppe. Oecologia 159:597-606.

Davies, K. W., J. D. Bates, and R. F. Miller. 2007. The influence of Artemisia tridentata ssp. wyomingensis on microsite and herbaceous vegetation heterogeneity. Journal of Arid Environments 69:441-457.

Dobrowolski, J. P., M. M. Caldwell, and J. H. Richards. 1990. Basin hydrology and plant root systems. In: C. B. Osmond, L. F. Pitelka, and G. M. Hidy [EDS.]. Plant biology of the basin and range. Ecological studies no. 80. Berlin, Germany: Springer-Verlag. p. 243-292.

Eckert, R. E., JR., F. F. Peterson, and J. T. Belton. 1986a. Relation between ecological-range condition and proportion of soil-surface types. Journal of Range Management 39:409-414.

Eckert, R. E., JR., F. F. Peterson, M. S. Meurisse, and J. L. Stephens. 1986b. Effects of soil-surface morphology on emergence and survival of seedlings in big sagebrush communities. Journal of Range Management 39:414-420.

ELdRIDGe, D. J., AND R. Rosentreter. 2004. Shrub mounds enhance water flow in a shrub-steppe community in southwestern Idaho, U.S.A. In:A. L. Hild, N. L. Shaw, S. E. Meyer, T. D. Booth, and D. E. McArthur [EDs.]. Seed and soil dynamics in shrubland ecosystems. Ogden, UT, USA: USDA Forest Service. p. 77-83.

Evans, R. A., AND J. A. Young. 1970. Plant litter and establishment of alien annual weed species in rangeland communities. Weed Science 18:697-703.

Evans, R. A., and J. A. Young. 1984. Microsite requirements for downy brome (Bromus tectorum) infestation and control on sagebrush rangelands. Weed Science 32(Suppl 1):13-17.

Griffith, A. B. 2010. Positive effects of native shrubs on Bromus tectorum demography. Ecology 91:141-154.

HARRIS, G. A. 1967. Some competitive relationships between Agropyron spicatum and Bromus tectorum. Ecological Monographs 37:89-111.

Hassan, M. A., and N. E. West. 1986. Dynamics of soil seed pools in burned and unburned sagebrush semi-deserts. Ecology 67:269-272.

Hector, A., B. Schmid, C. Beierkuhnlein, M. C. Caldeira, M. Diemer, P. G. Dimitrakopoulos, J. A. Finn, H. Freitas, P. S. Gilleer, J. Good, R. Harris, P. Högberg, K. Huss-Danell, J. Joshi, A. Jumpponen, C. Körner, P. W. Leadley, M. Loreau, A. Minns, C. P. H. Mulder, G. O’Donovan, S. J. Otway, J. S. Pereira, A. Prinz, D. J. Read, M. Scherer-Lorenzen, E. D. Schulze, A. S. D. Siamantzlouras, E. M. Spehn, A. C. Terry, A. Y. Troumbis, F. I. WoodWARD, S. YACHI, AND J. H. LAWTON. 1999. Plant diversity and productivity experiments in European grasslands. Science 286:1123-1127.

Hilty, J. H., D. J. Eldridge, R. Rosentreter, and M. C. Wicklow-Howard. 2003. Burning and seeding influence soil surface morphology in an Artemisia shrubland in southern Idaho. Arid Land Research and Management 17:1-11.

HOOVER, A. 2010. Relationships between soil heterogeneity and vegetation recovery in sagebrush steppe following wildfire and wind erosion [thesis]. Pocatello, ID, USA: Idaho State University. $100 \mathrm{p}$.

Hull, A. C., JR., and W. T. Hansen, JR. 1974. Delayed germination of cheatgrass seed. Journal of Range Management 27:366-368.

InOuYE, R. S., AND D. TILman. 1995. Convergence and divergence of old-field vegetation after $11 \mathrm{yr}$ of nitrogen addition. Ecology 76:1872-1887.

James, D. W., AND J. J. JuRINak. 1978. Nitrogen fertilization of dominant plants in the northeastern Great Basin desert. In: N. E. West and J. J. Skujins [EDS.]. Nitrogen in desert ecosystems. US/IBP Synthesis Series no. 9. Stroudsburg, PA: Dowden, Hutchinson and Ross, Inc. p. 219-231.

JAMES, J. J. 2008a. Effect of soil nitrogen stress on the relative growth rate of annual and perennial grasses in the Intermountain West. Plant and Soil 310:201-210.

JAMES, J. J. 2008b. Leaf nitrogen productivity as a mechanism driving the success of invasive annual grasses under low and high nitrogen supply. Journal of Arid Environments 72:1775-1784.

Lado, M., A. Paz, and M. Ben-Hur. 2004. Organic matter and aggregate size interactions in infiltration, seal formation, and soil loss. Soil Science Society of America Journal 68:935-942.

Lajtha, K., and W. H. Schlesinger. 1988. The biogeochemistry of phosphorus cycling and phosphorus availability along a desert soil chronosequence. Ecology 69:24-39.
Melgoza, G., R. S. Nowak, and R. J. Tausch. 1990. Soil water exploitation after fire: competition between Bromus tectorum (cheatgrass) and two native species. Oecologia 83:7-13.

Monaco, T. A., D. A. Johnson, J. M. Norton, T. A. Jones, K. J. Connors, J. B. Norton, and M. B. Redinbaugh. 2003. Contrasting responses of Intermountain West grasses to soil nitrogen. Journal of Range Management 56:282-290.

Norton, J. B., T. A. Monaco, J. M. Norton, D. A. Johnson, and T. A. Jones. 2004. Soil morphology and organic matter dynamics under cheatgrass and sagebrushsteppe plant communities. Journal of Arid Environments 57:445-466.

Ravi, S., P. D’Odorico, T. E. Huxman, and S. Coluins. 2010. Interactions between soil erosion processes and fires: implications for the dynamics of fertility islands. Rangeland Ecology \& Management 63:267-274.

R Development Core Team. 2009. R: a language and environment for statistical computing. Vienna, Austria: R Foundation for Statistical Computing. Available at: http://www.R-project.org.

Reichenberger, G., and D. A. Pyke. 1990. Impact of early root competition on fitness components of four semiarid species. Oecologia 85:159-166.

Reynolds, H. L., B. A. Hungate, F. S. Chapin III, and C. M. D’Antonio. 1997. Soil heterogeneity and plant competition in an annual grassland. Ecology 78:2076-2090.

Rimer, R. L., and R. D. Evans. 2006. Invasion of downy brome (Bromus tectorum L.) causes rapid changes in the nitrogen cycle. American Midland Naturalist 156:252-258.

Rusch, G., and J. M. Fernández-Palacios. 1995. The influence of spatial heterogeneity on regeneration by seed in a limestone grassland. Journal of Vegetation Science 6:417-426.

Sankey, J. B., M. J. Germino, and N. F. Glenn. 2009a. Aeolian sediment transport following wildfire in sagebrush steppe. Journal of Arid Environments 73:912-919.

Sankey, J. B., M. J. Germino, and N. F. Glenn. 2009b. Relationships of post-fire aeolian transport to soil and atmospheric conditions. Aeolian Research 1:75-85.

Sankey, J. B., N. F. Glenn, M. J. Germino, A. I. N. Gironella, and G. D. Thackray. 2010. Relationships of aeolian erosion and deposition with LiDAR-derived landscape surface roughness following wildfire. Geomorphology 119:135-145.

SAS InstituTE Inc. 2002-2008. SAS version 9.2. Cary, NC, USA: SAS Institute Inc.

Schlesinger, W. H., J. A. Raikes, A. E. Hartley, and A. F. Cross. 1996. On the spatial pattern of soil nutrients in desert ecosystems. Ecology 77:364-374.

Singer, M. J., And I. Shainberg. 2004. Mineral soil surface crusts and wind and water erosion. Earth Surface Processes and Landforms 29:1065-1075.

SperRy, L. J., J. Belnap, and R. D. Evans. 2006. Bromus tectorum invasion alters nitrogen dynamics in an undisturbed arid grassland ecosystem. Ecology 87:603-615.

Stewart, G., And A. C. Hull. 1949. Cheatgrass (Bromus tectorum L.)—an ecologic intruder in southern Idaho. Ecology 30:58-74.

Stringham, T. K., W. C. Krueger, and P. L. Shaver. 2003. State and transition modeling: an ecological process approach. Journal of Range Management 56:106-113.

StubBs, M. M., And D. A. Pyke. 2005. Available nitrogen: a time-based study of manipulated resource islands. Plant and Soil 270:123-133.

TiLman, D. 1997. Community invasibility, recruitment limitation, and grassland biodiversity. Ecology 78:81-92.

Tilman, D., J. Knops, D. Wedin, P. Reich, M. Ritchie, and E. Siemann. 1997a. The influence of functional diversity and composition on ecosystem processes. Science 277:1300-1302.

Tilman, D., C. L. Lehman, and K. T. Thomson. 1997b. Plant diversity and ecosystem productivity: theoretical considerations. Proceedings of the National Academy of Science 94:1857-1861.

Tylianakis, J. M., T. A. Rand, A. Kahmen, A. Klein, N. Buchmann, J. Perner, and T. Tscharntke. 2008. Resource heterogeneity moderates the biodiversity-function relationship in real world ecosystems. Public Library of Science Biology 6:947-956.

[USDA-NRCS] US Department of Agriculture-Natural Resources Conservation SeRvice. 2010. NCSS Web Soil Survey. Available at: http://websoilsurvey. nrcs.usda.gov/app. Accessed 23 June 2010.

Westerling, A. L., H. G. Hidalgo, D. R. Cayan, and T. W. Swetnam. 2006. Warming and earlier spring increase western U.S. forest wildfire activity. Science 313:940-943. 
Whisenant, S. G. 1990. Changing fire frequencies on Idaho's Snake River Plains: ecological and management implications. In: E. D. McArthur, E. M. Romney, S. D. Smith, and P. T. Tueller [comps.] . Cheatgrass invasion, shrub die-off, and other aspects of shrub biology and management. Ogden, UT, USA: USDA Forest Service, Intermountain Research Station. General Technical Report INT-276. p. 4-10.

Wood, M. K., W. H. Blackburn, R. E. Eckert, JR., and F. F. Peterson. 1978. Interrelations of the physical properties of coppice dune and vesicular dune interspace soils with grass seedling emergence. Journal of Range Management 31:189-192.

Wood, M. K., R. E. Eckert, JR., W. H. Blackburn, and F. F. Peterson. 1982. Influence of crusting soil surfaces on emergence and establishment of crested wheatgrass, squirreltail, Thurber needlegrass, and fourwing saltbush. Journal of Range Management 35:282-287.

Young, J. A., and Evans, R. A.. 1975. Germinability of seed reserves in a big sagebrush community. Weed Science 23:358-364. 